\title{
REAKSI SAHAM INDEKS JII TERHADAP PENGUMUMAN RESHUFFLE KABINET KERJA TAHUN 2015 DI BURSA EFEK INDONESIA
}

\author{
Herizka Ayuk Arviani \\ ayukarviani@gmail.com \\ Universitas Ahmad Dahlan \\ Rikha Muftia Khoirunnisa \\ Rikha@mgm.uad.ac.id \\ Universitas Ahmad Dahlan
}

\begin{abstract}
ABSTRAK
This study aims to determine the speed of JII stock price reaction on the Indonesia Stock Exchange around the date of the announcement of the Working Cabinet reshuffle and to analyze the difference in average trade volume in the period before and after the announcement of the Working Cabinet reshuffle. This data collection technique uses population techniques taken by 30 companies in the JII Index for the period June - November 2015 with observation period 10 days before and 10 days after the announcement. Analysis tools that are used to determine the reaction of stock prices before and after using one sample $\mathrm{t}$ test while the analytical tool to distinguish the average trading volume using paired sample $\mathrm{t}$ test using an alpha level $(\alpha)$ of $10 \%$. The results of the analysis of stock price reactions indicate that there is a JII stock price reaction at Indonesia Stock Exchange in the period before and after the announcement of the Working Cabinet reshuffle. Because abnormal returns occur at $\mathrm{H}-7, \mathrm{H}-4, \mathrm{H}-1, \mathrm{H} 0, \mathrm{H}+1, \mathrm{H}+7$ and $\mathrm{H}+10$. And the results of the average volume test that is there is a difference in the average trading volume before and after the announcement of the Working Cabinet reshuffle. This can be seen from the significance value lower than alpha $10 \%(0.033<0.0 .1)$.
\end{abstract}

Keyword : Cabinet reshuffle announcement; abnormal return; trading volume.

PENDAHULUAN

Keberadaan pasar modal memberi arti penting pada kegiatan perekonomian di Indonesia. Adanya pasar modal ini memunculkan kegiatan yang menjadi rutinitas seseorang dalam penanaman investasi di pasar modal, kegiatan tersebut tidak bisa lepas dari tujuan pasar modal itu sendiri. Kondisi harga saham yang terus berfluktuasi menjadi hal yang menarik dalam kegiatan berinvestasi karena dari investasi tersebut dapat menghasilkan return akan tetapi juga menghasilkan tingkat risiko yang sangat tinggi. Risiko ini tidak dapat dihilangkan tetapi investor dapat menghindari atau meminimalisir risiko dengan cara mengamati sumbersumber risiko dan setiap informasi yang mempengaruhi kegiatan investasi tersebut. Pada dasarnya informasi merupakan salah satu unsur penting yang tidak dapat dipisahkan dari aktivitas investor di pasar modal. Sebab dengan adanya informasi yang relevan, investor dapat memiliki gambaran mengenai risiko dan expected return dari suatu sekuritas dalam rangka menentukan keputusan serta strategi investasi untuk memperoleh tingkat pengembalian yang maksimal. Informasi yang dimaksud berkaitan dengan kondisi atau situasi yang dianggap relevan terhadap penilaian harga saham, baik berita resmi maupun isu. Informasi yang dapat mempengaruhi reaksi pasar modal tidak hanya berasal dari kondisi ekonomi, tetapi juga dapat berasal dari faktor-faktor non ekonomi seperti peristiwa hukum, peristiwa sosial dan gejolak politik di 
dalam Negri yang berpengaruh pada pergerakan saham di bursa efek.

Banyakya peristiwa yang timbul yang dapat mempengaruhi reaksipasar modal terdapat peristiwa yang terkadang tidak terlalu diperhatikan oleh investor dalam berinvestasi tetapi peristiwa tersebut dapat mempengaruhi hasil dari investasinya, seperti peristiwa politik yang dapat memberikan dampak positif maupun negatif terhadap penilaian para investor dan calon investor, terutama bagi investor asing dan calon investor asing. Menurut Alkaff (2010) dalam Wardhani (2013) peristiwa-peristiwa politik merupakan salah satu bagian dari lingkungan non ekonomi yang dapat berpengaruh pada kondisi pasar modal, karena dinamika situasi politik pada dasarnya juga berkaitan dengan stabilitas perekonomian suatu Negara. Kondisi politik yang stabil cenderung meningkatkan kinerja ekonomi suatu Negara. Hal ini dikarenakan rendahnya risiko kerugian yang diakibatkan oleh faktor non ekonomi, adanya peristiwa politik dapat mempengaruhi stabilitas Negara, seperti pemilihan umum, pergantian kepala Negara, pergantian struktur kabinet baru, ataupun berbagai kerusuhan politik. Peristiwa politik seperti perombakan susunan kabinet baru pada umumnya tidak sulit diduga karena tanda-tanda awal akan dilakukanya pergantian dan kapan akan di umumkan kabinet itu dapat dilihat melalui berbagai isu yang diberitakan dalam berbagai media. Perombakan susunan kabinet (reshuffle) memang tidak mengintervensi bursa saham secara langsung, tetapi informasi mengenai peristiwa ini dapat diserap oleh para pelaku pasar modal dan mempengaruhi pengambilan keputusan para investor, pada akhirnya pasar dapat bereaksi terhadap informasi tersebut dan harga saham mulai melakukan penyesuaian sehingga dapat dikatakan bahwa secara tidak langsung peristiwa ini mempengaruhi return saham dan volume perdagangan saham di bursa efek.
Pengaruh positif maupun negatif dalam pristiwa politik di harga saham itu tergantung dari pendapat masing-masing investor dan calon investornya. Menurut Francis (1992) dalam Lestari dan Subekti (2002) volume perdagangan saham dipandang sebagai indikator dari kuat atau lemahnya pasar. Jika volume perdagangan meningkat sejalan dengan pergerakan harga saham, baik naik ataupun turun, maka kemungkinan besar saham akan bertahan pada trend yang berlaku pada saat itu.

Apabila pasar bereaksi negatif return saham yang diperjualbelikan akan menurun dan apabila pasar bereaksi positif maka return saham yang diperjualbelikan akan meningkat. Secara tidak langsung peristiwa politik mempengaruhi aktivitas di bursa efek. Berdasarkan arti katanya, reshuffledapat berarti mengacak kembali atau merombak, dan Kabinet berarti badan atau dewan pemerintahan yang terdiri atas menteri (www.kbbi.web.id). Jadi reshuffle kabinet dapat diartikan sebagai proses mengacak kembali atau merombak badan atau dewan pemerintahan yang terdiri atas menteri. Perombakan kabinet merupakan salah satu peristiwa politik yang dilakukan oleh kepala pemerintahan seperti presiden sebagai langkah awal dalam pemerintahaan baru dan menentukan para menteri yang akan membantu dalam menjalankan pemerintahan dan kebijakankebijakan yang melayani rakyat.

Pada pemerintahan baru yang dipimpin oleh presiden Joko Widodo dan wakil Presiden Jusuf Kala, mereka membentuk kabinet baru yang diberi nama Kabinet Kerja dan terdiri dari 34 kementrian yang dibagi menjadi (20) dari kalangan Profesional dan (14) dari kalangan elit partai politik. Dari pembentukan kabinet baru tersebut Presiden Jokowi kurang puas terhadap kinerja beberapa menterinya. Kebijakankebijakan yang diambil oleh para menteri tidak sesuai dengan kenyataan di lapangan, karena itu rupiah menjadi anjlok dan para investor asing mulai 
menarik sahamnya. Sektor Bursa Efek Indonesia menyatakan bahwa IHSG menjadi turun hingga titik paling rendah. Banyak buruh pabrik yang di PHK karena kurs rupiah turun mempengaruhi harga saham, hal ini dilakukan perusahaan karena pendapatan perkapita industri juga turun. Munculnya berbagai isu yang membuat masyarakat resah tersebut menjadi salah satu alasan Presiden Jokowi mengambil keputusan untuk mengubah atau mengganti beberapa menterinya, dengan harapan adanya menteri baru yang lebih profesional dapat membawa perekonomian indonesia menjadi lebih baik dan maju.

\section{Rumusan Masalah}

1. Apakah terdapat abnormal return disekitar tanggal pengumuman reshuffle Kabinet Kerja ?

2. Apakah terdapat perbedaan rata-rata volume perdagangan sebelum dan sesudah pengumuman reshuffle Kabinet Kerja?

\section{REVIEW LITERATUR DAN HIPOTESIS}

\section{Landasan Teori \\ Pasar Modal}

Pasar modal adalah pertemuan antara pihak yang memiliki kelebihan dana dan pihak yang membutuhkan dana dengan cara memperjualbelikan sekuritas. Undang-undang pasar modal No. 8 tahun 1995 tentang pasar modal mendefinisikan pasar modal sebagai "kegiatan yang bersangkutan dengan penawaran umum dan perdagangan efek, perusahaan yang berkaitan dengan efek yang diterbitkannya, serta lembaga dan profesi yang berkaitan dengan efek" (Tandelilin, 2010).

\section{Investasi}

Investasi secara luas membutuhkan aset yang produktif untuk mengubah satu unit konsumsi yang ditunda untuk dihasilkan menjadi lebih dari satu unit mendatang. Dengan demikian, investasi dapat didefinisikan sebagai penunda konsumsi sekarang untuk dimasukan keaset produktif selama periode waktu tertentu (Jogiyanto, 2009). Investasi juga diartikan sebagai komitmen atas sejumlah dana atau sumber dana lainnya yang dilakukan pada saat ini, dengan tujuan memperoleh sejumlah keuntungan di masa datang. Menurut Sunariyah (2003) "Investasi adalah penanaman modal untuk satu atau lebih aktiva yang dimiliki dan biasanya berjangka waktu lama dengan harapan mendapatkan keuntungan di masamasa yang akan datang". Dewasa inibanyak negara-negara yang melakukan kebijaksanaan yang bertujuan untuk meningkatkan investasi baik domestik ataupun modal asing. Hal ini dilakukan oleh pemerintah sebab kegiatan investasi akan mendorong pula kegiatan ekonomi suatu negara, penyerapan tenaga kerja, peningkatan output yang dihasilkan, penghematan devisa atau bahkan penambahan devisa.

\section{Efisiensi Pasar}

Para ahli ekonomi mengatakan bahwa pasar modal yang efisien adalah pasar yang harga sekuritas-sekuritasnya telah mencerminkan semua informasi yang relevan. Semakin cepat informasi baru tercermin pada harga sekuritas, semakin efisien pasar modal tersebut maka akan sangat sulit bagi para pemodal untuk memperoleh tingkat keuntungan diatas normal secara konsisten dengan melakukan transaksi perdagangan di bursa efek. Efisiensi dalam artian ini sering juga disebut sebagai efisiensi pasar secara informasi (informationally efficient market) yaitu bagaimana pasar bereaksi terhadap informasi yang tersedia. Jadi harga saham yang berlaku di pasar modal sudah merefleksikan semua informasi yang tersedia (Jogiyanto, 2000) 


\section{Return}

Return adalah hasil yang diperoleh dari suatu kegiatan investasi. Return yang tinggi memberikan gambaran bahwa kompensasi yang diterima besar, demikian pula sebaliknya return yang rendah memberikan gambaran bahwa kompensasi yang diterima kecil. Return dapat berupa return realisasi yang sudah terjadi atau return ekspektasi yang belum terjadi tetapi diharapkan akan terjadi di masa mendatang (Tandelilin, 2010). Return realisasi dihitung berdasarkan data historis, yang juga digunakan sebagai salah satu alat pengukur kinerja perusahaan juga sebagai dasar penentuan return ekspektasi dan risiko di masa mendatang.

\section{Abnormal Return}

Abnormal return atau excess return merupakan kelebihan dari return yang sesungguhnya terjadi terhadap normal return. Normal return merupakan return ekspektasi (return yang diharapkan oleh investor). Dengan demikian return tidak normal (abnormal return) adalah selisih antara return sesungguhnya yang terjadi dengan return ekspektasi. Return sesungguhnya merupakan return yang terjadi pada waktu ke t yang merupakan selisih harga sekarang relatif terhadap harga sebelumnya. Return estimasi umumnya merupakan periode sebelum periode terjadinya peristiwa (Jogiyanto, 2000).

\section{Trading Volume Activity}

Likuiditas saham merupakan suatu indikator dan reaksi pasar terhadap suatu pengumuman yang diukur dengan Trading Volume Activity (TVA). Trading Volume Activity (TVA) atau aktivitas volume perdagangan merupakan suatu instrumen yang dapat digunakan untuk melihat reaksi pasar modal terhadap informasi melalui parameter pergerakan aktivitas volume perdagangan di pasar modal. Pendekatan trading volume activity (TVA) menurut Francis (1992) dalam Lestari dan Subekti (2002) volume perdagangan saham dipandang sebagai indikator dari kuat atau lemahnya pasar. Jika volume perdagangan meningkat sejalan dengan pergerakan harga saham, baik naik ataupun turun, maka kemungkinan besar saham akan bertahan pada trend yang berlaku pada saat itu. Sebaliknya, penurunan volume perdagangan dianggap sebagai indikator bahwa trend harga yang sedang berlaku akan berubah.

\section{Event Study (Studi Peristiwa)}

Penelitian Peterson (1986) dikutip dalam Primastono (2006) menyatakan event study adalah suatu pengamatan mengenai pergerakan harga saham di pasar modal untuk mengetahui apakah ada abnormal return yang diperoleh pemegang saham akibat dari suatu peristiwa tertentu. Menurut Jogiyanto (2003), event study merupakan studi yang mempelajari reaksi pasar terhadap suatu peristiwa yang informasinya dipublikasikan sebagai suatu pengumuman. Studi peristiwa bertujuan untuk mengukur hubungan antara suatu peristiwa yang mempengaruhi harga surat berharga dan return dari surat berharga tersebut serta menaksir apakah ada return abnormal atau excess return earned yang diperoleh pemegang saham dari adanya peristiwa tertentu (Tandelilin, 2001).

\section{Jendela Peristiwa}

Lamanya jendela tergantung jenis peristiwanya. Jika peristiwanya merupakan peristiwa yang nilai ekonomisnya dapat ditentukan dengan mudah oleh investor (misalnya pengumuman laba dan deviden), periode jendela dapat pendek. Hal ini disebabkan investor yang bereaksi dengan cepat terhadap informasi itu. Sebaliknya untuk peristiwa yang nilai ekonomisnya sulit ditentukan oleh investor (misalnya merger), investor akan membutuhkan waktu yang cukup lama untuk bereaksi terhadap informasi tersebut (Jogiyanto, 2000). 


\section{Penelitian Terdahulu}

\begin{tabular}{|c|c|c|c|c|}
\hline No & Keterangan & Peristiwa & $\begin{array}{l}\text { Variabel dan } \\
\text { Metode } \\
\text { Penelitian } \\
\end{array}$ & Hasil penelitian \\
\hline 1. & $\begin{array}{l}\text { Lamasigi } \\
\text { (2002) }\end{array}$ & \begin{tabular}{|l} 
Pergantian \\
Presiden \\
Republik \\
Indonesia \\
tanggal 233 \\
Juli 2001
\end{tabular} & \begin{tabular}{|l} 
Abnormal \\
return, Event \\
study
\end{tabular} & $\begin{array}{l}\text { - Tidak terdapat perbedaan } \\
\text { abnormal renurn sebelum dan } \\
\text { sesudah peristiwa. }\end{array}$ \\
\hline 2. & $\begin{array}{l}\text { Purboyono } \\
\text { (2002) }\end{array}$ & \begin{tabular}{|l} 
Reshuffle \\
Kabinet
\end{tabular} & \begin{tabular}{|l|} 
Abnormal \\
return, Event \\
study
\end{tabular} & $\begin{array}{l}\text { Terdapat perbedaan } \\
\text { abnormal return sebelum dan } \\
\text { sesudah peristiwa. } \\
\end{array}$ \\
\hline 3. & \begin{tabular}{|l} 
Meidawati \\
dan \\
Harimawan \\
$(2004)$
\end{tabular} & $\begin{array}{l}\text { Pemilihan } \\
\text { umum } \\
\text { legislatif } \\
\text { Indonesia }\end{array}$ & \begin{tabular}{|l|} 
Abnormal \\
return, TVA, \\
Event study
\end{tabular} & $\begin{array}{l}\text { - Terdapat perbedaan yang } \\
\text { signifikan antara rata-rata } \\
\text { abnormal retm sebelum } \\
\text { peristiwa dan sesudah } \\
\text { peristiwa lagislatif 2004. } \\
\text { - Terdapat perbedaan nilai } \\
\text { rata-rata volume perdagangan } \\
\text { saham pada periode sebelum } \\
\text { dan sesudah peristiwa pemilu } \\
\text { legislatif 2004. }\end{array}$ \\
\hline 4. & $\begin{array}{l}\text { Herigita } \\
(2005)\end{array}$ & \begin{tabular}{|l|} 
Non ckonomi \\
ledakan bom \\
di kawasan \\
kuningan \\
Jakarta \\
\end{tabular} & \begin{tabular}{|l|} 
Abnormal \\
return, Event \\
study
\end{tabular} & $\begin{array}{l}\text { - Terjadi abnormal retum } \\
\text { yang siknifikan pada } \\
\text { beberapa hari bursa sebelum } \\
\text { dan setelah event. }\end{array}$ \\
\hline 5. & $\begin{array}{l}\text { Annelia dan } \\
\text { Prihantoro } \\
\text { (2007) }\end{array}$ & \begin{tabular}{|l|} 
Reshuffle \\
Kabinet \\
Indonesia \\
Bersatu yang \\
dilakukan \\
tanggal $7 \mathrm{Mei}$ \\
2007
\end{tabular} & \begin{tabular}{|l|} 
Abnormal \\
return, Event \\
study
\end{tabular} & $\begin{array}{l}\text { - Secara uji rata-rata return tak } \\
\text { normal dan uji perbedaan } \\
\text { rata-rata abnormal refum } \\
\text { menunjukan bahwa } \\
\text { pengumuman reshuffle } \\
\text { kabinet tidak memberikan } \\
\text { pengaruh yang signifikan } \\
\text { terhadap pergerakan saham. }\end{array}$ \\
\hline \multirow[t]{2}{*}{6.} & $\begin{array}{c}\text { Nurhaeni } \\
\text { (2009) }\end{array}$ & \begin{tabular}{|l|} 
Pemilihan \\
umum \\
legislatif 9 \\
April 2009 \\
\end{tabular} & \begin{tabular}{|l|} 
Actual Return, \\
Abnormal \\
Return, dan \\
Trading Volume \\
\end{tabular} & $\begin{array}{l}\text { - Terdapat perbedaan rata-rata } \\
\text { TVA scbelum dan sesudah } \\
\text { peristiwa pemilu. }\end{array}$ \\
\hline & & & \begin{tabular}{|l|} 
activity, Market \\
Adjusted Model, \\
Event Study \\
\end{tabular} & \\
\hline 7. & $\begin{array}{c}\text { Trisnawati } \\
\text { dan Diantini } \\
\text { (2013) }\end{array}$ & \begin{tabular}{|l|} 
Pengumuman \\
reshuffle \\
Kabinet \\
Indonesia \\
Bersatu II \\
tanggal 18 \\
Oktoner 2011 \\
\end{tabular} & $\begin{array}{l}\text { Abnormal } \\
\text { return, Event } \\
\text { study }\end{array}$ & $\begin{array}{l}\text { - Secara uji signifikansi rata- } \\
\text { rata retum tak normal } \\
\text { menunjukan bahwa ada } \\
\text { reaksi harga saham LQ45 di } \\
\text { Bursa Efek Indonesia } \\
\text { sebelum dan sesudah } \\
\text { pengumuman reshuffle } \\
\text { Kabinet Indonesia Bersatu II } \\
\text { tanggal } 18 \text { Oktober } 2011 . \\
\text { - Secara Uji perbedaan rata- } \\
\text { rata abnormal retum } \\
\text { sebelum dan sesudah } \\
\text { peristiwa menunjukan bahwa } \\
\text { tidak ada perbedaan rata-rata } \\
\text { return tak normal pada } \\
\text { periode peristiwa sebelum } \\
\text { dan sesudah pengumuman } \\
\text { reshuffle Kabinet Indonesia } \\
\text { Bersatu II tanggal } 18 \text { Oktober } \\
\text { 2011. }\end{array}$ \\
\hline
\end{tabular}

\section{Hipotesis}

H1: Terdapat abnormal return disekitar tanggal pengumuman reshuffle Kabinet Kerja.

$\mathrm{H} 2$ : Terdapat perbedaan rata-rata volume perdagangan sebelum dan sesudah pengumuman reshuffle Kabinet Kerja.

\section{METODE PENELITIAN}

\section{Populasi dan Sampel}

Populasi dalam penelitian ini adalah semua perusahaan yang terdaftar di Jakarta Islamic Index (JII) selama periode Juni 2015 sampai November 2015 yang berjumlah 30 perusahaan. Indeks ini berisi emiten yang operasionalnya sejalan dengan syariah Islam dan disusun berdasarkan urutan kapitalisasi pasar.

Metode pengambilan sampel (teknik sampling) yang akan diuji dalam penelitian ini dilakukan menggunakan metode purposive sampling. Purposive sampling adalah teknik penentuan sampel dengan pertimbangan tertentu (Sugiyono, 2008)

\section{Definisi Operasional}

1. Variabel Independen

\section{Return}

Return adalah hasil yang diperoleh dari Investasi. Return dapat berupa return realisasi yang sudah terjadi maupun return ekspektasi yang belum terjadi namun diharapkan akan terjadi di masa mendatang (Jogiyanto 2000). Untuk menguji reaksi harga saham (abnormal return) menggunakan alat one sample $T$ test, dengan mengikuti tahapan sebagai berikut (Jogiyanto, 2000).

\section{Rata-rata Volume Perdagangan}

Aktivitas volume perdagangan merupakan suatu instrumen yang dapat digunakan untuk melihat reaksi pasar modal terhadap informasi melalui parameter pergerakan aktivitas volume perdagangan di pasar modal.

Indeks Jakarta Islamic Index (JII) Indeks ini berisi emiten yang operasinya sejalan dengan syariah islam dan disusun berdasarkan urutan kapitalisasi pasar. Indeks JII terdiri dari 30 saham yang telah ditetapkan oleh OJK (Otoritas Jasa Keuangan) setiap enam bulan sekali. Dalam penelitian ini data saham yang digunakan adalah data yang masuk dalam perhitungan JII periode Juni sampai dengan November 2015 


\section{Harga saham harian}

Harga saham harian yang digunakan dalam penelitian ini adalah 10 hari sebelum pengumuman dan 10 hari sesudah pengumuman reshuffle Kabinet Kerja.

\section{Teknik Analisis Data}

\section{Uji Asumsi Klasik}

Uji asumsi klasik menyatakan bahwa terdapat atau tidak terdapat penyimpangan asumsi klasik yang dapat terjadi dalam penggunaan model regresi linier berganda. Uji asumsi klasik yang digunakan dalam penelitian ini adalah uji normalitas. Uji normalitas dilakukan untuk mengetahui apakah data yang digunakan dalam penelitian ini berdistribusi secara normal atau tidak. Untuk membuktikan apakah data dalam penelitian ini berdistribusi normal atau tidak digunakan uji One-Sample Kolmogorov Smirnov-Z. Suatu data dikatakan berdistribusi normal jika nilai probabilitas (p) uji One-Sample Kolmogorov Smirnov- $Z>0,1(10 \%)$, dan sebaliknya jika nilai probabilitas (p) uji One-Sample Kolmoorov SmirnovZ < $0,1(10 \%)$, maka data tersebut tidak berdistribusi secara normal (Ghozali, 2009). Alat uji yang digunakan apabila datanya normal maka menggunakan alat uji one sample t-test untuk hipotesis pertama dan uji beda dua rata-rata berpasangan yaitu (paired sample T-test) untuk hipotesis kedua. Apabila datanya tidak normal maka menggunakan alat uji Wilcoxon Signed Rank Test dengan tingkat signifikan atau alpha $10 \%$.

\section{Alat Analisis Data}

1. Menggunakan event-date tanggal pengumuman Reshuffle Kabinet Kerja 12 Agustus 2015.

2. Periode pengujian (event-window) adalah periode pada saat diperkirakan pasar bereaksi atas adanya pengumuman reshuffle Kabinet Kerja yang ditandai dengan adanya perubahan return abnormal yang signifikan, 10 hari sebelum dan 10 hari sesudah eventdate.

3. one sample t-test

Pengujian dilakukan untuk mengetahui signifikansi akumulasi ratarata return abnormal yang ada pada peristiwa. Digunakan one sample t-test untuk mengetahui bahwa akumulasi rata-rata abnormal tersebut secara statistik tidak sama dengan nol, dengan menggunakan tingkat probabilitas sebesar $10 \%(\alpha=0,1)$. Dari perhitungan tersebut, akan dihasilkan t-hitung yang kemudian akan dibandingkan dengan ttabel (df-k) untuk membuat kesimpulan, dengan ketentuan bila thitung > ttabel, maka Hal diterima. Sedangkan bila t hitung < t-tabel, maka Ha1 ditolak atau jika probabilitas $>0,1$ (10\%) maka H0 diterima dan jika probabilitas < 0,1 (10\%) maka $\mathrm{Ha}$ diterima.

4. Paired sample t-test

Periode penelitian dalam event study ini meliputi 21 hari bursa periode jendela yang terbagi dalam 10 hari sebagai pre-event, 1 hari sebagai event day dan 10 hari post-event

\section{HASIL PENELITIAN DAN PEMBAHASAN}

\section{Hasil Analisis Data Hipotesis Pertama Uji Normalitas}

Tabel 4.6 Hasil Pengujian Normalitas Data

\begin{tabular}{|l|l|l|l|c|l|}
\hline Hari & Sign & keterangan & Hari & Sign & keterangan \\
\hline 11 & & & 0 & 0.781 & Normal \\
\hline-10 & 0.972 & Normal & 1 & 0.858 & Normal \\
\hline-9 & 0.841 & Normal & 2 & 0.893 & Normal \\
\hline-8 & 0.778 & Normal & 3 & 0.895 & Normal \\
\hline-7 & 0.795 & Normal & 4 & 0.916 & Normal \\
\hline-6 & 0.137 & Normal & 5 & 0.373 & Normal \\
\hline-5 & 0.865 & Normal & 6 & 0.460 & Normal \\
\hline-4 & 0.657 & Normal & 7 & 0.749 & Normal \\
\hline-3 & 0.415 & Normal & 8 & 0.988 & Normal \\
\hline-2 & 0.634 & Normal & 9 & 0.619 & Normal \\
\hline-1 & 0.955 & Normal & 10 & 0.959 & Normal \\
\hline-
\end{tabular}

Dari tabel di atas dapat dijelaskan bahwa hasil uji data normalitas adalah semua data normal. Hal itu karena nilai signifikan yang lebih besar dari $10 \%$ sehingga disimpulkan bahwa data tersebut normal. Langkah selanjutnya yaitu 
menguji abnormal return harian dengan alat uji one sample $t$ test. Berikut adalah hasil dari perhitungannya.

Tabel 4.7 one sample $t$ test

\begin{tabular}{|l|l|l|}
\hline Hari & Sign & Keterangan \\
\hline-10 & 0.334 & Tidak Signifikan \\
\hline-9 & 0.878 & Tidak Signifikan \\
\hline-8 & 0.267 & Tidak Signifikan \\
\hline-7 & 0.087 & Signifikan \\
\hline-6 & 0.120 & Tidak Signifikan \\
\hline-5 & 0.809 & Tidak Signifikan \\
\hline-4 & 0.077 & Signifikan \\
\hline-3 & 0.910 & Tidak Signifikan \\
\hline-2 & 0.583 & Tidak Signifikan \\
\hline-1 & 0.057 & Signifikan \\
\hline 0 & 0.065 & Signifikan \\
\hline 1 & 0.038 & Signifikan \\
\hline 2 & 0.450 & Tidak Signifikan \\
\hline 3 & 0.286 & Tidak Signifikan \\
\hline 4 & 0,215 & Tidak Signifikan \\
\hline 5 & 0.145 & Tidak Signifikan \\
\hline 6 & 0.200 & Tidak Signifikan \\
\hline 7 & 0.100 & Signifikan \\
\hline 8 & 0.284 & Tidak Signifikan \\
\hline 9 & 0.771 & Tidak Signifikan \\
\hline 10 & 0,002 & Signifikan \\
\hline
\end{tabular}

Dari hasil uji one sample t-test di atas dapat dijelaskan bahwa yang mengalami abnormal return terdapat pada $\mathrm{H}-7, \mathrm{H}-4, \mathrm{H}-1, \mathrm{H}, \mathrm{H}+1 \mathrm{H}+7$ dan $\mathrm{H}+10$. Sedangkan yang lainnya tidak mengalami abnormal return karena signifikansinya lebih besar dari pada 10\%. Dapat ditarik kesimpulan bahwa menerima Ha:Terdapat abnormal return disekitar tanggal pengumuman reshuffle Kabinet Kerja (H1 terdukung).

\section{Hipotesis Kedua \\ Uji Normalitas}

\begin{tabular}{|l|l|l|}
\hline Periode & Sign & Keterangan \\
\hline Sebelum & 0.953 & Normal \\
\hline Sesudah & 0.998 & Normal \\
\hline
\end{tabular}

Dari hasil di atas dapat dijelaskan bahwa data rata-rata volume perdagangan bersifat normal. Karena nilai signifikansinya lebih besar dari alpha $10 \%$.

Langkah selanjutnya yaitu menguji beda rata-rata volume perdagangan menggunakan paired sample t-test. Berikut adalah hasil uji paired sample test:

\begin{tabular}{|l|l|l|}
\hline Periode & Sign & Keterangan \\
\hline Sebelum- Sesudah & 0.033 & Signifikan \\
\hline
\end{tabular}

Dari hasil di atas dapat dijelaskan bahwa hasil uji rata-rata volume menggunakan paired sample t test dengan nilai sign $(0,033<0,1)$ yang berarti menerima Ha: Terdapat perbedaan rata rata volume perdagangan sebelum dan sesudah pengumuman reshuffle Kabinet Kerja ( $\mathrm{H}_{2}$ terdukung).

\section{Pembahasan}

Berdasarkan dari uji hipotesis pertama yang menggunakan alat uji one sample $t$ test hasilnya adalah terdapat abnormal return disekitar tanggal pengumuman reshuffle Kabinet Kerja. Hal ini dapat disimpulkan karena abnormal return terjadi pada $\mathrm{H}-7, \mathrm{H}-4, \mathrm{H}-1, \mathrm{H} 0, \mathrm{H}+1$, $\mathrm{H}+7$ dan $\mathrm{H}+10$ sedangkan hari yang lainnya terbukti secara statistik tidak signifikan. Signifikansi rata-rata abnormal return yang terjadi sebelum periode peristiwa menunjukkan bahwa sudah ada kebocoran informasi dari pengumuman reshuffle Kabinet Kerja. Pada $\mathrm{H} 0, \mathrm{H}+1, \mathrm{H}+7$ dan $\mathrm{H}+10$ pasar bereaksi dan terjadi abnormal return yang merupakan imbas/efek dari pengumuman reshuffle yang dilakukan oleh Presiden Joko Widodo. Hasil penelitian tidak berbeda dengan penelitian yang dilakukan oleh Trisnawati dan Diantini (2013) yang berjudul "Analisis Pengaruh Reshuffle Kabinet Indonesia Bersatu II Terhadap Harga Saham LQ45 DI Bursa Efek Indonesia". Hasil penelitianmenyimpulkan bahwa secara uji signifikansi return tak normal menunjukkan bahwa ada reaksi harga saham LQ45 di Bursa Efek Indonesia sebelm dan sesudah peristiwa pengumuman reshuffle Kabinet Indonesia Bersatu II tanggal 18 Oktober 2011 dengan adanya 4 hari bursa yang memperoleh return tak normal yaitu pada $\mathrm{t}-3, \mathrm{t}-2, \mathrm{t}-1$ dan $\mathrm{t}+1$.

Hasil uji hipotesis kedua yaitu terdapat perbedaan rata-rata volume perdagangan sebelum dan sesudah pengumuman reshuffle Kabinet Kerja. 
Menurut Francis (1992) dalam Lestari dan Subekti (2002) volume perdagangan saham dipandang sebagai indikator dari kuat atau lemahnya pasar. Jika volume perdagangan meningkat sejalan dengan pergerakan harga saham, baik naik ataupun turun, maka kemungkinan besar saham akan bertahan pada trend yang berlaku pada saat itu.

Kondisi seperti di atas kemungkinan terjadi karena sentimen para pelaku pasar modal (investor) pada pengumuman nama-nama menteri yang diganti dan mengisi pos-pos strategis, khususnya berhubungan dengan perekonomian dan kebijakan-kebijakan yang dapat memberi dampak yang positif bagi pelaku pasar. Seperti Menteri Polhukam, Menko Perekonomian, Menko Kementrian, Mentri Perdagangan, Mentri Perencanaan Pembangunan beserta Kepala Bappenas, dan Sekretaris Kabinet yang kurang sesuai dengan yang diharapkan oleh para pelaku investor.

Pendapat dari para pelaku pasar modal (investor) menginginkan namanama yang mengisi pos tersebut berasal dari kalangan profesional yang menguasai bidangnya dan mempunyai rekam jejak yang bagus. Para investor berpendapat bahwa kalau nama menteri yang mengisi pos-pos itu berasal dari kalangan partai politik itu diragukan, karena takutnya banyak kepentingan politik. Kondisi seperti itulah yang membuat para pelaku pasar bersentimen negatif dan berdampak pada harga saham yang menurun, sehingga return dan abnormal return menurun (negatif), tetapi ada sebagian para pelaku pasar yang memanfaatkan kondisi itu sehingga saat harga saham menurun tingkat penjualan volume perdagangan saham justru meningkat

\section{KESIMPULAN DAN SARAN}

\section{Kesimpulan}

1. Terdapat reaksi harga saham JII di Bursa Efek Indonesia pada periode sebelum dan sesudah pengumuman reshuffle kabinet kerja. Hal ini berdasarkan hasil uji one sample t test dapat dijelaskan bahwa yang mengalami abnormal return terjadi pada $\mathrm{H}-7 \quad(0.087<0.1)$, H-4 $(0.077<0.1)$, $\mathrm{H}-1 \quad(0.057<0.1), \mathrm{H} 0(0.065<0.1), \mathrm{H}+1$ $(0.038<0.1), \mathrm{H}+7 \quad(0.100 \leq 0.1)$ dan $\mathrm{H}+10$ $(0.002<0.1)$. Sedangkan yang lainnya tidak mengalami abnormal return karena signifikansinya lebih besar dari pada $10 \%$ sehingga $\mathrm{H} 1$ diterima.

2. Terdapat perbedaan rata-rata volume perdagangan sebelum dan sesudah pengumuman reshuffle kabinet kerja. Hal ini berdasarkan bahwa hasil uji rata-rata volume menggunakan paired sample $t$ test dengan nilai sign $(0.033<0.1)$ yang berarti $\mathrm{H} 2$ diterima.

\section{Saran}

1. Perlu dilakukan penelitian yang lebih lanjut tentang peristiwa-peristiwa mengenai kondisi politik di Indonesia.

2. Para pelaku pasar (investor) tidak hanya mempertimbangkan hal internal perusahaan yang akan ditanamkan modalnya, tetapi memperhatikan kondisi eksternal juga termasuk kondisi politik saat ini.

3. Penelitian ini hanya menggunakan indeks JII, sehingga tidak mencerminkan kondisi pasar secara keseluruhan. Maka untuk penelitian selanjutnya disarankan untuk menggunakan sampel penelitian yang lebih luas seperti IHSG.

4. Bagi pemerintah hendaknya menjaga kondisi politik yang stabil karena kondisi politik yang tidak stabil dapat menimbulkan konflik yang dapat mempengaruhi penilaian para investor baik investor dalam negeri maupun luar negeri yang akan menanamkan modalnya di Indonesia.

\section{DAFTAR PUSTAKA}

Annelia, Corry PH dan prihantoro, 2007. Pengaruh Resuffle Kabinet 
Terhadap Pergerakan harga Saham LQ45 di Indonesia, <http://www.researchgate.net/public ation/266228446_>. [di akses tanggal 26 Agustus 2015].

Ardial,Wendy, 2006. Analisi Reaksi Harga Saham LQ45 Terhadap Kenaikan Harga BBM Tanggal 1 Oktober 2005. Skripsi.Yogyakarta:UII.

Diantini, Nyoman Ayu dan Ni Komang Dian Trisnawati. Tanpa tahun. Analisis Pengaruh Resuffle Kabinet Indonesia Bersatu II Terhadap Harga Saham LQ45 di Bursa Efek Indonesia.

$<$ http://ojs.unud.ac.id/index.php/Manajeme n/article/view/7405/5654>.

[di akses tanggal 26 Agustus 2015].

Ghozali, Imam. 2009. Aplikasi Analisis Multivariate Dengan Program SPSS, Edisi Keempat, Penerbit Universitas Diponegoro.

Herigita, Sandi. 2004. Reaksi Pasar Modal Indonesia Terhadap Peristiwa Non Ekonomi (Studi Kasus Peristiwa Bom Kuningan 9 September 2004). Jurnal TPSDP Universitas Jember.

Husnan, Suad. 2001. Dasar-Dasar Teori Portofolio dan Analisis Sekuritas, Edisi ketiga Yogyakarta: UPP AMP YKPN. IDX Annualy Statistics, 2011. http://www.idx.co.id. [di akses tanggal 16 September 2015].

Jogiyanto, H. M, 2000, Teori Portofolio dan Analisis Investasi, Ed. 2, Yogyakarta: BPFE Universitas Gadjah Mada.

Jogiyanto, H.M, 2003. Teori Portofolio dan Analisis Investasi . Edisi Ketiga, Yogyakarta: BPPE. Universitas Gadjah Mada.
Jogiyanto, H.M, 2009. Teori Portofolio dan Analisis Investasi . Edisi Keempat, Yogyakarta: BPPE. Universitas Gadjah Mada.

Jogiyanto H, M. 2014. Teori dan Praktik Portofolio dengan Excell. Jakarta: Penerbit Salemba Empat.

Lestari, Sri dan Imam Subekti. 2002. Asosiasi Antara Pengumuman Kabinet Baru Tanggal 23 Agustus 2000 Dengan Stock Price dan Trading Volume Activity di PT Bursa Efek Jakarta.

$<$ http://tema.ub.ac.id/index.php/tema/articl e/view/161>. [di akses tanggal 20 Oktober 2015].

Lamasigi, Treisye Ariance, 2002. Reaksi Pasar Modal Terhadap Peristiwa Pergantian Presiden Republik Indonesia 23 Juli 2001: Kajian Terhadap Return Saham LQ-45 di PT. Bursa Efek Jakarta, Proceeding Simposium Nasional Akuntansi V, Hal 273-285.

Meidawati, dan Mahendra Harimawan, 2004. "Pengaruh Pemilihan Umum Legislatif Indonesia Tahun 2004 Terhadap Return Saham dan Volume Perdagangan Saham LQ-45 di PT. Bursa Efek Indonesia (BEJ)", SINERGI Kajian Bisnis dan Manajemen, Vol 7 No. 1, 89-101.

Nurhaeni, Nunung, 2009. Dampak Pemilihan Umum Legislatif Indonesia Tahun 2009 Terhadap Abnormal Return dan Aktivitas Volume Perdagangan Saham di BEI (uji kasus pada saham yang terdaftar dalam kelompok perusahaan LQ45). Tesis. Semarang: Universitas Dipenogoro. <

http://eprints.undip.ac.id/24209/>. [di akses tanggal 20 Oktober 2015]. 
Primastono, Indra. 2006. Analisis Perbandingan Peristiwa Pengumuman Kabinet Gotong Royong dan Kabinet Indonesia Bersatu Terhadap Reaksi Saham dan Likuiditas Saham (studi kasus saham LQ45 di PT. Bursa Efek Indonesia). Tesis. Semarang: Universitas Dipenogoro.

<http://eprints.undip.ac.id/17797/1/INDR A_PRIMASTONO.pdf $>$. [di akses tanggal 20 Oktober 2015].

Purboyono, Temmy, 2002, "Pengaruh Peristiwa pada Reshuffle Kabinet Persatuan Nasional Terhadap Reaksi Harga Saham di Bursa Efek Jakarta", Tesis Program Pascasarjana Magister Manajemen Universitas Diponegoro.

Santoso, Singgih. 2002. SPSS Versi 11.5. Cetakan Kedua. Jakarta: Gramedia. Sugiyono, 2008. Metoda Penelitian Bisnis. Cetakan Keduabelas. Bandung: Alfabeta.

Susilo D, Bambang . 2003. Pasar Modal (mekanisme perdagangan saham, analisis sekuritas, dan strategi investasi di B.E.I.. Yogyakarta:UPP STIM YKPN.

Tandelilin. 2001. Analisis Investasi dan Manajemen Portofolio, Edisi Pertama. Yogyakarta:BPFE.

Tandelilin, 2007. Analisis Investasi dan Manajemen Portofolio, Cetakan kedua. Yogyakarta:BPFE.

Tandelilin, E. 2010. Portofolio dan investasi. edisi pertama, Yogyakarta: penerbit KANISIUS.

Tjiptono Darmadji, Hendry M.Fakhrudin. 2011. Pasar Modal di Indonesia. Edisi ketiga, Jakarta:penerbit Salemba Empat.
Trianto, Galih. 2011. Analisis Reaksi Harga Saham LQ45 Terhadap Kenaikan Tarif Dasar Listrik (TDL) Tanggal 12 Juli 2010. Skripsi. Yogyakarta:UAD.

Wardani, Laksmi Swastika. 2013. Reaksi Pasar Modal Indonesia Terhadap Peristiwa Pemilihan Gubernur DKI Jakarta Putaran II 2012 (Event Study pada Saham Anggota Indeks Kompas 100)

.www.jimfeb.ub.ac.id/index.php/jimfeb/art icle/view 